\title{
Quandaries of ethics education
}

\author{
Bert Gordijn $\cdot$ Henk ten Have
}

Published online: 18 December 2012

(C) Springer Science+Business Media Dordrecht 2013

If we are to believe Plato, Socrates seems to have had a rather cheerful outlook on ethics teaching. In the Protagoras he argues that virtue consists entirely of knowledge. More specifically, Socrates develops a hedonistic view, in which pleasure determines happiness. Virtue is the knowledge needed to attain pleasure and happiness. Thus, virtues and having a virtuous character mean that we have knowledge of what yields pleasure overall. However, Socrates not only thinks that knowledge is a necessary condition for virtuous behavior; it is also a sufficient condition (cf. Homiak 2011). This Socratic view is not in accord with common sense. The latter suggests that achieving a virtuous character and displaying good behavior call for more than just the acquisition of knowledge. If one rationally believes something to be right, this insight alone cannot guarantee that one behaves virtuously. After all, people do not always act rationally and are often encouraged by temptations of all kinds to act against their better rational judgment. If they are incontinent or weak-willed, they may therefore easily sway from the right track. Unfortunately, incontinence (acrasia) is widespread, at least according to common sense (cf. Homiak 2011).

Contrary to the mainstream view Socrates holds that people who leave the right track are not weak-willed but ignorant. Acrasia is not possible, at least not with someone who has true knowledge. If somebody really knows goodwhat will bring long term pleasure at the end of the dayand evil, nothing will overpower him so that he acts against his insights. If one truly masters the art of measuring

B. Gordijn $(\bowtie)$

Dublin, The Netherlands

e-mail: bert.gordijn@dcu.ie

H. ten Have

Paris, France pleasure, equally considering current and future pleasures and pains, why would one choose a suboptimal course of action (cf. Woodruff 2010). "...no man voluntarily pursues evil, or that which he thinks to be evil." (Plato, Protagoras). Actions taken in ignorance are involuntary. Therefore, they are not blameworthy. If Socrates is right in holding that knowledge is sufficient to guarantee virtuous behavior, moral improvement can be achieved through appropriate education. In fact, Socrates regards this as his personal mission as he constantly endeavors to educate his fellow Athenians (Plato, Apology). However, Socrates is not convinced that he has true knowledge of the virtues. Therefore, teaching ethics cannot merely be a matter of transferring knowledge. Instead it is essential to have elaborate discussions about the virtues. Only through thorough debate can we gain true understanding of the virtues. That is why Socrates is one of the most influential ethics teachers ever-without having left behind one single written word.

Aristotle's outlook on ethics teaching is less upbeat, but most likely more realistic. Knowledge alone does not guarantee good behaviour. Acrasia is a reality. Both people's behaviour and character are in large part the product of habituation. Aristotle clearly sees the limits of Socrates' exclusively intellectual approach to moral improvement: “....argument and teaching... are not powerful with all men, but the soul of the student must first have been cultivated by means of habits..." (Aristotle, X 9). In order to enhance the changes of an appropriate upbringing legislation is needed: "... it is difficult to get from youth up a right training for virtue if one has not been brought up under right laws; for to live temperately and hardily is not pleasant to most people, especially when they are young. For this reason their nurture and occupations should be fixed by law..." (Aristotle, X 9). However, not only minors need legislation. Good laws are 
equally vital for adults: “...they must, even when they are grown up, practise and be habituated... we shall need laws for this as well, and generally speaking to cover the whole of life; for most people obey necessity rather than argument, and punishments rather than the sense of what is noble" (Aristotle, $X$ 9). In his view there should be no ethics classes for wrongdoers; instead offenders are to be put in jail or otherwise punished.

This does not mean that Aristotle gives up on ethics teaching. It will just not be effective, if habituation has gone wrong in the first place. Accordingly, he states at the beginning of Nicomachean Ethics: “....any one who is to listen intelligently to lectures about what is noble and just...must have been brought up in good habits" (Aristotle, I 4). Although Aristotle's ideas of the prospects of ethics teaching are more moderate than Socrates', he still operates on the assumption that the study of ethics tends to improve moral behaviour of apprentices, barring students who are completely spoiled by bad upbringing. At least that is his stated goal in the Nicomachean Ethics: “...we are inquiring not in order to know what virtue is, but in order to become good..." (Aristotle, II 2). Similar ideas about moral reflection and the study of ethics and their improving effects on character and behavior have been advanced by scores of other philosophers.

In the last couple of years the idea that studying ethics leads to the improvement of moral behaviour has been put to the test by Eric Schwitzgebel. In fact he seems to have unleashed a true battery of empirical studies of ethicists' moral behaviour. His research is based on the hypothesis that if the study of ethics and morality has a positive effect on moral behavior, academics fortunate enough to devote an important part of their life to ethics would have to behave better than those who are not focusing on moral reflection. However, again and again Schwitzgebel's studies fail to corroborate the moral superiority of ethicists' behavior. The book lending behavior of ethicists, for example, is not better than the behavior of non-ethicists. Rather, the opposite seems to be true (Schwitzgebel 2009). Also, ethicists do not execute the civic duty of voting more reliably or often than non-ethicists (Schwitzgebel and Rust 2010). Furthermore, audiences in ethics sessions at American Philosophical Association conferences do not behave any more courteously than do audiences in sessions that are not focused on ethics (Schwitzgebel et al. 2012). Finally, at the 2007 Pacific Division meeting of the American Philosophical
Association, the majority of respondents stated "that ethicists do not, on average, behave better than non-ethicists" (Schwitzgebel and Rust 2009, p. 1043).

Of course the empirical study of the relationship between moral reflection and real-world moral behavior is still at an early stage of development. However, if further empirical inquiries continue to demonstrate that the study of ethics is behaviorally inert or perhaps even detrimental, we will increasingly have to rethink the role of ethics teaching in medical, engineering and business schools. For sure, studying ethics may have intrinsic value, apart from any possibly beneficial impact on character and behavior. Nevertheless, it will be difficult to push the ethics education agenda in medicine, engineering and business, if we have to give up on the idea of moral improvement ensuing from our educational endeavors. Against this backdrop the editors invite more contributions on the quandaries of ethics education such as the first two papers in the issue at hand (Barilan and Brusa 2013; Cigman 2013).

\section{References}

Aristotle, Nicomachean Ethics. (trans: Ross, W.D.). Accessed at: http://classics.mit.edu/Aristotle/nicomachaen.html.

Barilan, Y. M., and M. Brusa 2013. Deliberation at the hub of medical education: beyond virtue ethics and codes of practice. Medicine Health Care and Philosophy 16(1): this issue.

Cigman, R. 2013. How not to think: Medical ethics as negative education. Medicine Health Care and Philosophy 16(1): this issue.

Homiak, M. 2011. Moral character. In The Stanford encyclopedia of philosophy (Spring 2011 Edition), ed. Edward N. Zalta. Accessed at: http://plato.stanford.edu/archives/spr2011/entries/moral-character/.

Plato, Protagoras (trans: Benjamin Jowett). Accessed at: http://www. gutenberg.org/files/1591/1591-h/1591-h.htm.

Plato, Apology (trans Benjamin Jowett). Accessed at: http://classics. mit.edu/Plato/apology.html.

Schwitzgebel, E. 2009. Do ethicists steal more books? Philosophical Psychology 22(6): 711-725.

Schwitzgebel, E., and J. Rust. 2009. The moral behavior of ethicists: Peer opinion. Mind 118(472): 1043-1059.

Schwitzgebel, E., and J. Rust. 2010. Do ethicists and political philosophers vote more often than other professors? Review of Philosophy and Psychology 1(2): 189-199.

Schwitzgebel, E., J. Rust, L. Huang, A. Moore, and J. Coates. 2012. Ethicists' courtesy at philosophy conferences. Philosophical Psychology 25(3): 331-340.

Woodruff, P. 2010. Plato's shorter ethical works. In The Stanford encyclopedia of philosophy (Summer 2010 Edition), ed. Edward N. Zalta. Accessed at: http://plato.stanford.edu/archives/sum2010/ entries/plato-ethics-shorter/. 